\title{
Za Viliamom Turčánym (1928 - 2021)
}

\section{Lenka Rišková}

DOI: https://doi.org/10.31577/slovlit.2021.68.4.7

ORCID: 0000-0001-9465-3712

D esiateho mája 2021 zomrel majster básnického umenia a skutočný filozof poézie, PhDr. Viliam Turčány, CSc., Dr.h.c. - literárny vedec, básnik, prekladatel', vysokoškolský pedagóg, človek vel'kého ducha. Odkaz jeho práce i osobnosti je v mnohých oblastiach zásadný. Možno ho charakterizovat' nielen ako ohromujúcu sumarizáciu výsledkov dôsledného materiálového výskumu, ale zároveň aj ako inšpiratívnu a stále aktuálnu výzvu k nasledujúcemu bádaniu. Viliam Turčány bol vskutku neobyčajným zjavom v slovenskej literatúre a slovenskej literárnej vede. Profesorka Eva Fordinálová raz pôsobivo vystihla, že klúčovým slovom jeho práce bolo SLOVO - úcta k slovu a vnímanie slova ako daru. Jeho básnická tvorba, prekladatel'ská činnost' (úzko spätá s priam dôverným vztahom k jazykom, z ktorých prekladal) i vedecká práca tvoria vzácnu jednotu. V jeho osobe dokonale splynul vedec s básnikom a jeho slová - či už odeté do šatu básne, alebo vedeckej štúdie - vždy nadchýnali celého človeka, rozum aj dušu. Podl'a profesora Daniela Škovieru bol Viliam Turčány básnik i človek hodný rešpektu, v ktorom sa harmonicky zlúčil talent s učenostou, bol poeta natus aj doctus.

Viliam Turčány sa narodil 24. februára 1928 v Suchej nad Parnou. V rokoch 1948 - 1952 absolvoval štúdium na Filozofickej fakulte Slovenskej univerzity v Bratislave odbor slovenský jazyk a literatúra - francúzsky jazyk a literatúra. Nasledujúcich tridsat'šest' rokov (1952-1988), vrátane dvojročného pôsobenia na poste lektora slovenskej a českej literatúry na univerzite v Neapole v rokoch 1972 - 1974, venoval svoj bohatý tvorivý i výskumný potenciál Slovenskej akadémii vied. Bol vedeckým pracovníkom Literárnovedného ústavu SAV, ktorý sa neskôr premenoval na Ústav slovenskej literatúry SAV. V roku 2013 sme ho na tomto pracovisku privítali pri príležitosti jeho osemdesiatych piatych narodenín, ked'sa na jeho počest' konal vedecký seminár pripomínajúci mnohé oblasti jeho rôznorodej literárnovednej i umeleckej aktivity. Posledný raz bol u nás v roku 2014 ako host' seminára Pamät' literárnej vedy o Jozefovi Ambrušovi.

Doménou literárnohistorického bádania Viliama Turčányho bol bezpochyby výskum verzológie a historickej poetiky. Svoj prehl'ad v dejinách európskej poézie od antiky cez taliansku a francúzsku renesanciu po modernu potvrdil 
458 mnohými publikáciami. Známe sú predovšetkým jeho štúdie vydané v dvoch zväzkoch pod súhrnným názvom Cestami poézie (2003). V pôsobivých analýzach a pozorných interpretáciách diel antických, renesančných i klasicistických básnikov poukázal na zásadné paralely medzi európskou a domácou slovenskou literatúrou. Na základe prekladu Eugena Paulinyho prebásnil zo staroslovienčiny do modernej slovenčiny Proglas od Konštantína Filozofa (1996, 1998, 2004, 2013). Súbežne venoval Proglasu a odkazu Konštantína Filozofa niekol'ko interpretačných a výkladových štúdií a článkov. Osobitné miesto v jeho výskume mal však bezpochyby Ján Hollý - vôbec prvou vedeckou prácou Viliama Turčányho bola práve kniha Na krásnú zahradu Hollého Jána (1972) a neskôr nasledovala kritická edícia Hollý vo výbere a interpretácii Viliama Turčányho (1976). V monografii Rým v slovenskej poézii (1975) zase sledoval vývin rýmu od najstarších čias po jeho podoby v medzivojnovej avantgardnej poézii. Vel'ká čast' výsledkov jeho dôsledného výskumu z oblasti literárnej histórie, poetiky či umeleckého prekladu je dostupná v časopiseckých štúdiách.

Obdivuhodná bola aj Turčányho prekladatel'ská činnost', v ktorej naplno využil bohatý potenciál filologicky a esteticky erudovaného literárneho vedca. Početné sú najmä jeho preklady z poézie talianskych renesančných, no tiež antických básnikov. V spolupráci s Jozefom Felixom pripravil preklad Danteho Božskej komédie, časti Peklo a Očistec preložili spoločne (1964, 1982), na preklade tretej časti Raj pracoval Viliam Turčány po smrti Jozefa Felixa už sám (vydal ho v roku 1986). S Jozefom Felixom spolupracoval aj pri preklade výberu zo stredovekých provensálskych básnikov Danteho Trubadúri (1972) a pri básnických výberoch Michelangela Buonarrotiho Tebe to, láska, hovorím (1963) a Som ako mesiac (1975). Okrem toho vydal preklady z talianskej renesančnej lyriky Trochu si spolu pohovorme, láska (1968), z tvorby básnikov takzvanej sicílskej školy Ó, svieža ruža voňavá (1972) a pripravil aj antológiu talianskej lyriky od stredoveku po 20. storočie $V y$ jasné sladké vlny (1978). Z francúzskych básnikov Turčánymu učarovali Pierre de Rostand a Sully Prudhomme. Z antickej poézie pripravil zase výber z Ovídiových Metamorfóz-Premeny (1970), Vergíliove Bukoliky (1993) a v edícii pre mládež jeho Aeneas. Prekladatel'ské zručnosti prezentoval aj v knihách Petrarcov vavrín (1974) a Podl'a vôd a vol'ných polí (1978). Obsiahly výber z prekladatel'skej tvorby Viliama Turčányho vyšiel v knižnom súbore Preklady v roku 1980.

Ako básnik debutoval Viliam Turčány zbierkou Jarky v kraji (1957). Nasledovali zbierky V toku (1965), U kotvy (1972), Oliva (1974), Aj most som ja (1977) s príznačným palindrómom v názve, výber Piesne (1978) či zbierka sonetov Venuše slovenského praveku (1979, v spoluautorstve s Jozefom Vladárom). V knihe Rozhovor (1984) jeho verše sprevádzajú kresby Vincenta Hložníka. Silné etické cítenie Viliama Turčányho reprezentuje zbierka Srdce, DrSc. (1987). Návratom ku krásam rodného kraja je súbor $A z ̌$ do najd'alšich končín (1988). V zozname jeho básnických zbierok nemožno prehliadnut ani bibliofilské vydanie výberu Učitelia Slovanov (1990). Typickú hru s jazykom potvrdzujú aj d'alšie zbierky, opät' s palindrómom v názve: Oheň z Neho (1992), Rada a dar (1995), Srdce zve a vyzváňa (1998), V okraje jarkov (2000), Obrazy, čiže Mária i rám (2002). V roku 2018 vyšiel posledný výber Dar.

Viliam Turčány vnímal poéziu ako posolstvo, a tak pristupoval aj k svojej práci - či už vlastnými veršami, alebo dôslednými analýzami básnických textov 
poukazoval na zabudnuté hodnoty klasickej poézie. Vnímal ju s vel'kou pokorou. 459

Uvedomoval si jej obrovskú výpovednú hodnotu, ale aj schopnost' katarzie. Bola preňho prostriedkom osobného i celospoločenského očistenia, povznesenia ducha, a predovšetkým jasným ukazovatel'om pravých hodnôt. No bola aj jeho vlastnou životnou cestou.

Prínos Viliama Turčányho pre rozvoj slovenskej kultúry bol mnohokrát ocenený na národnej i medzinárodnej úrovni. Z radu ocenení možno spomenút Pribinov kríž I. triedy za prínos v literárnej vede a prekladatel'stve (2002), Cenu Karla Čapka (1993), prekladatel'skú Cenu Jána Hollého $(1968,1981,1986)$, cenu prezidenta Talianskej republiky za rozvíjanie slovensko-talianskych kultúrnych vzt'ahov (2002), Cenu Zory Jesenskej za celoživotné prekladatel'ské dielo (2007) alebo výročnú cenu predsedu Národnej rady Slovenskej republiky (2012).

Vztah Viliama Turčányho k poézii a vôbec $\mathrm{k}$ literatúre, no predovšetkým jeho vztah k jazyku ako takému, ku klasickým jazykom a k jazykom velikánov renesančnej poézie, a zároveň hlboký a úprimný vzt'ah a úcta k vlastnému jazyku a vlastnej literárnej tradícii, ktoré neustále potvrdzoval intenzívnym štúdiom, boli výnimočné a neopakovatel'né. Bez zveličovania možno konštatovat', že jeho dielo predstavuje nielen pre slovenskú literárnu vedu, ale vôbec pre celú slovenskú spoločnost' jeden zo základných kameňov slovenskej kultúrnej identity.

Mgr. Lenka Rišková, PhD.

Ústav slovenskej literatúry SAV

Dúbravská cesta 9

84104 Bratislava

Slovenská republika

E-mail: lenka.riskova@gmail.com 